УДК 338.23

DOI https:// doi.org/10.32850/2414-4207.2019.11-1.08

\title{
СУТНІСТЬ ДЕРЖАВНОЇ ПОЛІТИКИ У СФЕРІ ЗАБЕЗПЕЧЕННЯ ЕКОНОМІЧНОЇ БЕЗПЕКИ ДЕРЖАВИ
}

\author{
Кошиков Денис Олександрович, \\ кандидат юридичних наук, \\ старший викладач кафедри \\ поліцейської діяльності \\ та публічного адміністрування \\ факультету № 3 \\ (Харківський національний \\ університет внутрішніх справ, \\ м. Харків, Україна)
}

У статті автором проаналізовано зміст і основні ознаки понять «політика» та «державна політика», що дозволило сформулювати авторське визначення терміна «державна політика у сфері забезпечення економічної безпеки держави». Встановлено, що метою державної політики у сфері гарантування економічної безпеки держави є створення належних умов для впорядкування та розвитку суспільних економічних відносин, забезпечення реалізації соціально-економічних прав і свобод громадян, а також створення умов для подальшого розвитку і зростання національної економіки та забезпечення ії конкурентоспроможності. Досягнення задекларованої мети насамперед забезпечується шляхом створення належної законодавчої бази з питань гарантування економічної безпеки, а також формуванням дієвого адміністративно-правового механізму реалізації ії положень та приписів. Проаналізовані ознаки та завдання державної політики у сфері гарантування економічної безпеки держави. На підставі сформульованих завдань державної політики у сфері гарантування економічної безпеки держави здійснено класифікацію їі основних підвидів: нормативно-інституційна політика у сфері економічної безпеки; політика забезпечення економічних прав громадян; політика розвитку національної економіки й економічних відносин; політика цифровізації економічних відносин, забезпечення економічної та фінансової грамотності населення; правоохоронна політика у сфері економічної безпеки. Наголошено, що у структурі державної політики з гарантування економічної безпеки держави можна виділити декілька складових елементів: нормативно-правовий, до якого входять законодавчі та підзаконні акти $з$ питань гарантування економічної безпеки, а також регулювання економічних відносин; інституційний, який складають уповноважені органи публічної адміністрації та їх посадові особи, які мають нормативно закріплені повноваження щодо гарантування економічної безпеки держави; організаційний, який, на нашу думку, містить принципи, форми та методи реалізації державної політики у сфері гарантування економічної безпеки.

Ключові слова: політика, державна політика, економічна безпека, економічна безпека держави. 


\title{
THE ESSENCE OF GOVERNMENT POLICY IN THE AREA OF ENSURING ECONOMIC SECURITY OF THE STATE
}

\author{
Koshykov Denys Oleksandrovych, \\ Candidate of Juridical Sciences, \\ Senior Instructor at the Department of \\ Police Activity and Public Administration \\ of the Faculty № 3 \\ (Kharkiv National University \\ of Internal Affairs, Kharkiv, Ukraine)
}

The author analyzes the content and main features of the concepts of "politics" and "state policy", which made it possible to formulate the author's definition of the term "state policy in the sphere of economic security of the state". It is established that the purpose of the state policy in the sphere of ensuring the economic security of the state is to create the proper conditions for the ordering and development of social economic relations, ensuring the realization of socio-economic rights and freedoms of citizens, as well as creating the conditions for the further development and growth of the national economy and ensuring its competitiveness. The achievement of the declared goal is, first of all, ensured by the creation of a proper legislative framework on economic security, as well as by the establishment of an effective administrative and legal mechanism for the implementation of its provisions and regulations. Signs and tasks of the state policy in the sphere of ensuring the economic security of the state are analyzed. On the basis of the formulated tasks of the state policy in the sphere of economic security of the state, the classification of its main subspecies was carried out: normative-institutional policy in the sphere of economic security; policy of ensuring the economic rights of citizens; policy of development of national economy and economic relations; policy of digitalization of economic relations, ensuring of economic and financial literacy of the population; law enforcement policy in the field of economic security. It is emphasized that in the structure of the state policy for ensuring the economic security of the state, several components can be distinguished: regulatory and legal, which includes legislative and by-laws on ensuring economic security, as well as regulation of economic relations; institutional, composed of authorized public administration bodies and their officials, who have statutory powers to ensure the economic security of the state; organizational, which, in our opinion, contains the principles, forms and methods of implementing public policy in the field of economic security.

Key words: politics, state policy, economic security, economic security of state.

Постановка проблеми. У сучасних умовах існування глобального світу можна з упевненістю стверджувати, що існування незалежної, суверенної та соціально спрямованої держави, якою визначена Україна в Основному законі, можливе багато в чому завдяки економіки, яка надійно функціонує, захищена від зовнішніх і внутрішніх загроз.

Гарантування економічної безпеки країни $є$ органічною складовою частиною процесу формування дієвої системи національної безпеки, адже погіршення економічної ситуації може призвести до занепаду промислового виробництва, банкрутства банків, недоотримання державним бюджетом коштів, що спрямовуються на розвиток стратегічних галузей, а також соціальну підтримку населення, що може спричинити негативні наслідки у вигляді безробіття, зростання злочинності, загроз масових заворушень тощо.

Саме тому держава в особі уповноважених органів повинна визначити стратегічний курс розвитку всіх ключових галузей із метою впорядкування економічних 
відносин, забезпечення їхньої стабільності та прогнозованості, виробляти адекватні заходи зі зростання добробуту населення з урахуванням об'єктивних економічних законів. Такий курс в узагальненому вигляді має назву «державна політика», отже, можна зробити висновок, що державна політика у сфері гарантування економічної безпеки потребує більш детального наукового опрацювання у світлі визначених нами проблем суспільного та світового розвитку.

Аналіз останніх публікацій. Питання державної політики у сфері економічної безпеки висвітлювалися у працях В. Волошина, 3. Гбур, Ю. Ковбасюка, О. Лаврука, I. Петренко, В. Сорокіна, I. Шевчука [1-7]. У сучасних умовах розвитку держави, зумовлених світовою економічною кризою, трансформацією національного законодавства, що регулює економічні відносини в України, виникає потреба в переосмисленні змісту державної політики у сфері гарантування економічної безпеки держави, що надає цій публікації актуальності.

Метою статті варто визначити формулювання поняття державної політики у сфері економічної безпеки, окреслення їі мети, завдань та основних типів (напрямів реалізації).

Виклад основного матеріалу. У загальносоціальному сенсі політика визначається як процес, під час якого група людей, чиї погляди або інтереси на початковій стадії різняться, ухвалює колективне рішення щодо згуртування групи загалом, що запроваджується як спільна лінія поведінки [8, с. 282]. Політику також розглядають як сукупність трьох взаємопов'язаних аспектів, як-от: 1) сфера громадського життя; 2) один із видів активності суб'єктів у соціумі; 3) певний тип соціальних стосунків (між індивідами, невеликими групами тощо) [9, с. 267].

О. Васильєв у процесі розгляду політики як прояву соціальної активності виділяє в ній окремі елементи:

Розмаїття поглядів. Політикою передбачається, що існують різноманітні погляди на певні ситуації, події, явища тощо. Ці думки найчастіше пов'язані або з формулюванням кінцевої мети, або з розглядом тих чи інших способів досягнення мети.

Механізм вироблення рішень. Саме політикою визначаються шляхи досягнення згоди стосовно ухвалення колективних рішень. Такі шляхи переважно включають три типи засобів: переконування, проведення переговорів, ухвалення остаточного рішення.

Процедура ухвалення рішень. Політика передбачає, що ухвалене рішення конкретна спільнота людей вважатиме авторитетним. Це рішення стає політикою як лінією поведінки для означеної групи людей [10].

Водночас у багатьох наукових працях політику розглядають із позицій діяльності держави, як мистецтво (науку чи практику) керування державою або різними політичними утвореннями [11, с. 344].

Наведене визначення цілком відповідає предмету цієї наукової статті, а тому, досліджуючи роль держави в гарантуванні економічної безпеки, варто вести мову про особливий вид політики - державну політику у сфері гарантування економічної безпеки. Теоретичні роботи у сфері організації та реалізації державної політики визначають їі як:

- діяльністьдержавитаїї інститутів, спрямовану назабезпечення порядку всуспільстві, узгодження та підпорядкування різноманітних соціальних інтересів, досягнення суспільної злагоди й організації управління суспільним розвитком [12, с. 116];

- стабільну, організовану й цілеспрямовану діяльність (бездіяльність) державних інститутів, здійснювану ними безпосередньо чи опосередковано щодо певних проблеми або сукупності проблем, які впливають на життя суспільства [13, с. 6];

- свідому діяльність владних структур та інститутів державного управління різних рівнів, спрямовану на регулювання суспільних відносин, забезпечення їхньої 
стабільності та розвитку відповідно до визначених цілей, це спосіб суспільного врядування, що передбачає розроблення і здійснення політичних програм економічного, соціального, культурного і політичного розвитку [14, с. 503].

Стосовно соціальної сфери діяльності держави можна зазначити наукові напрацювання сутності державної політики у сферах культури, освіти тощо:

- державна молодіжна політика - це специфічна діяльність держави та ії інститутів стосовно молоді, що ставить за мету створення необхідних умов та гарантій для ії соціального становлення та розвитку, реалізації ії творчого потенціалу як у власних інтересах, так і в інтересах держави [15, с. 78];

- державна політика у сфері культури - це організована діяльність держави, спрямована на створення сприятливих умов національно-культурного розвитку, задоволення інтелектуальних і духовних потреб людини, збереження культурної спадщини та підтримання єдності нації [16];

- державна політика у сфері освіти розуміється як система напрямів діяльності держави на шляху розв' язання найбільш важливих проблем і вирішення завдань, що постають перед системою освіти [3, с. 205].

Із наведених загальнотеоретичних і спеціальних визначень державної політики можна зробити висновок про ії типові ознаки:

- державна політика пов'язується 3 певними діяннями держави в особі ії органів і уповноважених посадових осіб. Крім того, у реалізації державної політики можуть брати участь політичні партії як добровільне об'єднання громадян - прихильників певної загальнонаціональної програми суспільного розвитку, що має своєю метою сприяння формуванню і вираженню політичної волі громадян. У механізмі реалізації державної політики не виключається також участь представників громадянського суспільства;

- державна політика може виражатися як у діяльності, так і в бездіяльності уповноважених суб'єктів: публічної адміністрації, політичних партій тощо;

- метою державної політики варто визначити врегулювання певних суспільних відносин за окремими сферами суспільного життя з метою їх упорядкування, захисту та подальшого розвитку;

- ключовим аспектом державної політики є забезпечення прав і свобод фізичних і юридичних осіб, сприяння їхній реалізації, а також захисту та відновлення в разі порушень;

- державна політика, з одного боку, має засновуватися на положеннях чинного законодавства, а із другого - створювати правові норми, що спрямовані на вирішення відповідних соціально-економічних проблем, урегулювання й охорону суспільних відносин;

- реалізація заходів державної політики забезпечується наявністю в певних суб'єктів адміністративно-владних повноважень, зокрема щодо застосування заходів адмінітсративного примусу;

- державна політика супроводжується ухваленням державно-вданих управлінських рішень у вигляді нормативних та індивідуальних управлінських актів, а також програм соціально-економічного розвитку.

Засновуючись на вищевикладеному, маємо висловити думку, що державна політика у сфері гарантування економічної безпеки держави являє собою закріплену чинним законодавством України систему законодавчих, організаційних, управлінських заходів, яка реалізується в основному уповноваженими суб'єктами публічної адміністрації за участі політичних партій, інститутів громадянського суспільства та представників бізнес-середовища $з$ метою впорядкування та розвитку суспільних економічних відносин, 
забезпечення реалізації соціально-економічних прав і свобод громадян, а також створення умов для подальшого розвитку і зростання національної економіки та забезпечення конкурентоспроможність держави у світовому економічному середовищі.

У структурі державної політики із гарантування економічної безпеки держави можна виділити декілька складових елементів:

1) нормативно-правовий, до якого входять законодавчі та підзаконні акти з питань гарантування економічної безпеки, а також регулювання економічних відносин. До нормативно-правового елементу належать також державні та регіональні програми соціально-економічного розвитку;

2) інституційний, який складають уповноважені органи публічної адміністрації та їх посадові особи, які мають нормативно закріплені повноваження щодо гарантування економічної безпеки держави, у частині видання нормативних та індивідуальних актів управління, застосування заходів державного примусу. До інституційної складової частини доцільно також віднести Верховну Раду України, наділену повноваженнями з ухвалення законів України в зазначеній сфері, Президента України, який є Головою Ради національної безпеки і оборони України, інші державні органи, наділені функціями щодо захисту економічних прав, свобод фізичних та юридичних осіб, а також держави;

3) організаційний, який, на нашу думку, містить принципи, форми та методи реалізації державної політики у сфері гарантування економічної безпеки держави.

У свою чергу, метою державної політики у сфері гарантування економічної безпеки держави є створення належних умов для впорядкування та розвитку суспільних економічних відносин, забезпечення реалізації соціально-економічних прав і свобод громадян, а також створення умов для подальшого розвитку і зростання національної економіки та забезпечення ії конкурентоспроможності. Досягнення задекларованої мети насамперед забезпечується шляхом створення належної законодавчої бази 3 питань гарантування економічної безпеки, а також формуванням дієвого адміністративно-правового механізму реалізації ії положень та приписів.

Серед основних ознак державної політики у сфері гарантування економічної безпеки держави такі:

1. Відповідає положенням чинного законодавства України та враховує об'єктивні закони економіки.

2. Спрямована на забезпечення реалізації соціально-економічних прав і свобод громадян, а також створення умов для подальшого розвитку і зростання національної економіки.

3. Реалізується спеціально визначеними суб'єктами публічної адміністрації. До зазначених процесів можуть бути залучені політичні партії, а також представники громадянського суспільства та бізнес-середовища.

4. Реалізується за допомогою спеціальних норм права, які мають здебільшого адміністративно-правову природу, оскільки ухвалюються уповноваженими органами публічної адміністрації на виконання законодавчих положень. У такому разі можна говорити про наявність механізму адміністративно-правового регулювання гарантування економічної безпеки держави.

5. Забезпечується певною сукупністю нормативно визначених форм і методів, серед яких чільне місце посідають видання актів управління, а також застосування методів переконання і примусу.

6. Багаторівневість реалізації (загальнодержавний, регіональний, місцевий рівні).

7. Багатовекторність політики, оскільки економічна безпека держави включає в себе фінансову, макроекономічну, виробничу, енергетичну, зовнішньоекономічну й інвестиційно-інноваційну безпеки. 
8. Системність і наступність, які проявляються у створенні системи спеціально уповноважених органів іï здійснення, наявності механізму ухвалення стратегічних i тактичних управлінських рішень, контролю за отриманим результатом та здійснення коригування за необхідності.

9. Критеріальність, яка полягає в тому, що держава в особі уповноважених органів виробляє систему критеріїв та показників ефективності політики у сфері гарантування економічної безпеки.

Далі маємо зробити аналіз нормативно-правової бази з питань економічного розвитку держави та гарантування їі економічної безпеки. Так, у Стратегії сталого розвитку «Україна - 2020» наголошується, що в Україні першочерговою є реалізація таких реформ і програм:

1. Дерегуляція та розвиток підприємництва. Створення сприятливого середовища для ведення бізнесу, розвитку малого і середнього підприємництва, залучення інвестицій, спрощення міжнародної торгівлі та підвищення ефективності ринку праці.

2. Податкова реформа. Мета реформи - побудова податкової системи, яка $\epsilon$ простою, економічно справедливою, з мінімальними затратами часу на розрахунок і сплату податків, створює необхідні умови для сталого розвитку національної економіки, забезпечує достатнє наповнення державного бюджету України та місцевих бюджетів.

3. Програма енергонезалежності. Головне завдання - гарантування енергетичної безпеки і перехід до енергоефективного й енергоощадного використання та споживання енергоресурсів з упровадженням інноваційних технологій [17].

Господарський кодекс України до основних напрямів економічної політики України відносить:

1) структурно-галузеву політику, спрямовану на здійснення державою прогресивних змін у структурі економіки, що забезпечують конкурентоспроможність вітчизняної продукції та зростання рівня життя населення;

2) інвестиційну політику, спрямовану на створення суб'єктам господарювання необхідних умов для залучення і концентрації коштів на потреби розширеного відтворення основних засобів виробництва;

3) політику інституційних перетворень, спрямовану на формування раціональної багатоукладної економічної системи шляхом трансформування відносин власності, здійснення роздержавлення економіки, приватизації та націоналізації виробничих фондів;

4) цінову політику, спрямовану на дотримання необхідної паритетності цін між галузями та видами господарської діяльності, а також забезпечення стабільності оптових і роздрібних цін;

5) антимонопольно-конкурентну політику, спрямовану на створення оптимального конкурентного середовища діяльності суб' єктів господарювання;

6) бюджетну політику, спрямовану на оптимізацію та раціоналізацію формування доходів і використання державних фінансових ресурсів, підвищення ефективності державних інвестицій в економіку;

7) податкову політику, спрямовану на забезпечення економічно обгрунтованого податкового навантаження на суб'єктів господарювання;

8) грошово-кредитну політику, спрямовану на забезпечення економіки економічно необхідним обсягом грошової маси, досягнення ефективного готівкового обігу;

9) валютну політику, спрямовану на встановлення і підтримання паритетного курсу національної валюти щодо іноземних валют; 
10) зовнішньоекономічну політику, спрямовану на регулювання державою відносин суб'єктів господарювання з іноземними суб'єктами господарювання та захист національного ринку [18].

Закон «Про національну безпеку України» вказує на те, що фундаментальними національними інтересами України є:

- сталий розвиток національної економіки, громадянського суспільства і держави для забезпечення зростання рівня та якості життя населення;

- інтеграція України в європейський політичний, економічний, безпековий, правовий простір, набуття членства в Свропейському Союзі та в Організації Північноатлантичного договору, розвиток рівноправних взаємовигідних відносин з іншими державами.

Державна політика у сферах національної безпеки й оборони спрямовується на забезпечення воєнної, зовнішньополітичної, державної, економічної, інформаційної, екологічної безпеки, кібербезпеки України тощо [19].

Крім того, відповідно до положень цього Закону, Служба безпеки України гарантує державну безпеку, здійснюючи з неухильним дотриманням прав і свобод людини і громадянина контррозвідувальний захист державного суверенітету, конституційного ладу і територіальної цілісності, оборонного і науково-технічного потенціалу, кібербезпеки, економічної та інформаційної безпеки держави.

Зважаючи на згадані нормативно-правові акти, положення яких визначають сутність і ознаки державної політики у сфері гарантування економічної безпеки держави, іiї ключовими завданнями можна окреслити такі:

1) удосконалення положень чинного законодавства України в економічній сфері шляхом розроблення ключових законів і ухвалення стратегічних програм у сфері економічної безпеки;

2) формування дієвої інституційної системи із забезпечення реалізації стратегії економічної безпеки держави, визначення ії ключових суб'єктів, меж їхніх повноважень, основи взаємодії та координації;

3) залучення до розроблення й реалізації економічних безпекових програм і заходів представників бізнес-середовища, профільних професійних союзів, представників малого підприємництва, економічної наукової спільноти тощо;

4) підвищення стійкості економіки до впливу зовнішніх і внутрішніх викликів і загроз, поліпшення інвестиційного клімату у країні, удосконалення процесів бюджетного планування та соціально-економічного розвитку регіонів, удосконалення системи фінансової безпеки, оптимізація регулятивного та податкового навантаження;

5) здійснення формування належної економічної культури та фінансової грамотності населення;

6) упровадження в систему економічних відносин сучасних інформаційно-комунікаційних технологій, що дозволяють удосконалити процеси здійснення економічних операцій, мінімізувати ризики сторін, забезпечити для населення зручність отримання фінансових та інших послуг;

7) здійснення гармонічної інтеграції України в європейський та світовий економічний безпековий простір, забезпечення розвитку рівноправних взаємовигідних економічних відносин з іншими державами, а також участі держави у протидії світовим економічним загрозам і транснаціональній економічній злочинності;

8) створення правових і організаційних підстав для реалізації громадянами своїх економічних прав і свобод (права на власність, на підприємницьку діяльність тощо), забезпечення їх охорони, а також захисту та відновлення в разі порушень; 
9) формування принципово нової системи контрольних і правоохоронних органів, на які будуть покладені завдання у сфері гарантування економічної безпеки, виключення із предметної компетенції інснучих суб'єктів правоохоронної діяльності невластивих їм повноважень, зокрема щодо втручання у сферу економічних відносин;

10) здійснення належного захисту інформаційно-комунікаційної інфраструктури економіки України: платіжних систем, інформаційних банків, реєстрів даних, персональних даних суб'єктів економічної діяльності тощо;

11) створення належних умов та вжиття системних заходів щодо протидії корупціï, порушенням антимонопольного законодавства, фінансовим і економічним злочинам, особливо тим, що вчиняються організованими злочинними угрупованнями, протидія легалізації коштів, отриманих незаконним шляхом.

Ураховуючи сформульований нами перелік завдань, які має вирішувати державна політика у сфері гарантування економічної безпеки, ми можемо виділити такі ії підвиди:

1. Нормативно-інституційна політика у сфері економічної безпеки.

2. Політика забезпечення економічних прав громадян.

3. Політика розвитку національної економіки й економічних відносин.

4. Політика цифровізації економічних відносин, забезпечення економічної та фінансової грамотності населення.

5. Правоохоронна політика у сфері економічної безпеки.

Із проведеного дослідження доцільно зробити деякі висновки й узагальнення:

1. Державна політика у сфері гарантування економічної безпеки держави являє собою закріплену чинним законодавством України систему законодавчих, організаційних, управлінських заходів, яка реалізується в основному уповноваженими суб'єктами публічної адміністрації за участі політичних партій, інститутів громадянського суспільства та представників бізнес-середовища 3 метою впорядкування та розвитку суспільних економічних відносин, забезпечення реалізації соціально-економічних прав і свобод громадян, а також створення умов для подальшого розвитку і зростання національної економіки та забезпечення конкурентоспроможності держави у світовому економічному середовищі.

2. У структурі державної політики з гарантування економічної безпеки держави можна виділити декілька складових елементів: нормативно-правовий, до якого входять законодавчі та підзаконні акти з питань гарантування економічної безпеки, а також регулювання економічних відносин; інституційний, який складають уповноважені органи публічної адміністрації та їх посадові особи, які мають нормативно закріплені повноваження щодо гарантування економічної безпеки держави; організаційний, який, на нашу думку, містить принципи, форми та методи реалізації державної політики у сфері гарантування економічної безпеки.

3. Виходячи із завдань державної політики у сфері гарантування економічної безпеки держави, іï підвидами виступають нормативно-інституційна політика у сфері економічної безпеки, політика забезпечення економічних прав громадян, політика розвитку національної економіки й економічних відносин, політика цифровізації економічних відносин, забезпечення економічної та фінансової грамотності населення, правоохоронна політика у сфері економічної безпеки.

\section{Список використаних джерел:}

1. Волошин В. Державна політика забезпечення економічної безпеки держави в умовах гібридних загроз. Бизнес Інформ. 2018. № 9 (488). С. 19-24.

2. Гбур 3. Інституційне забезпечення економічної безпеки України. Інвестиціӥ: практика та досвід. 2018. № 3. С. 98-102. 
3. Державна політика : підручник / Нац. акад. держ. упр. при Президентові України ; ред. кол. : Ю. Ковбасюк (голова), та ін. Київ : НАДУ, 2014. 448 с.

4. Лаврук О. Сутність поняття державної політики. Університетські наукові записки. 2018. № № 3-4. C. 254-263.

5. Петренко I. Сутність державної політики та державних цільових програм. Віче. 2011. № 10. C. 23-25.

6. Сорокіна В. Теоретико-правові засади економічної безпеки. Державне будівництво та місиеве самоврядування. 2016. № 31. С. 205-217.

7. Шевчук I. Загрози економічній безпеці України в умовах політико-економічних реалій. Університетські наукові записки. 2018. № 1. С. 175-185.

8. Міллер Д. Політика. Енииклопедія політичної думки / редкол.: К. Сігов, В. Скуратівський, Л. Фінберг. Пер. 3 англ. Н. Лисюк, С. Альошкіної, І. Підлуської. Київ : Дух і Літера, 2000. С. 282-283.

9. Политология : словарь-справочник / М. Василик и др. Москва : Гардарики, 2001. 328 c.

10. Васильєв О. Концептуалізація поняття «державна політика»: сучасне розуміння. Державне будівництво. 2014. № 1. URL: http://nbuv.gov.ua/UJRN/DeBu_2014_1_7 (дата звернення: 18.02.2020).

11. Большая актуальная политическая энциклопедия / под общ. ред. А. Белякова, О. Матвейчева. Москва : Эксмо, 2009. 412 с.

12. Логунова М., Шевченко М. Концептуальні засади теорії політики. Київ : Вид-во УАДУ, 1999. 343 с.

13. Державна політика: аналіз та механізми ії впровадження в Україні / кол. авт. ; за заг. ред. В. Ребкала, В. Тертички. Київ : Вид-во УАДУ, 2000. 453 с.

14. Політологія. Кн. Друга : Політика і держава / ред. : А. Колодій, Л. Климанська, Я. Космина. Київ : Ельга-Н ; Ніка-Центр, 2000. 584 с.

15. Кривачук Л. Державна молодіжна політика 3 питань неповнолітніх в Україні (державно-управлінський аспект) : монографія. Львів : ЛДФА, 2009. 240 с.

16. Борисенко Д. Державна політика у сфері культури: іï сутність та особливості реалізації. Теорія та практика державного управління. 2017. Вип. 4. C. 123-131. URL: http://nbuv.gov.ua/UJRN/Tpdu_2017_4_19 (дата звернення: 18.02.2020).

17. Про Стратегію сталого розвитку «Україна-2020» : Указ Президента України від 12 січня 2015 р. № 5/2015. URL: https://zakon.rada.gov.ua/laws/show/5/2015 (дата звернення: 15.03.2020).

18. Господарський кодекс України : Закон України від 16 січня 2003 р. № 436-IV. URL: https:/ / zakon.rada.gov.ua/laws/show/436-15 (дата звернення: 17.03.2020).

19. Про національну безпеку України : Закон України від 21 червня 2018 р. № 2469-VIII. URL: https://zakon.rada.gov.ua/laws/show/2469-19 (дата звернення: 15.03.2020). 